\title{
The release of terpenes during storage of biomass
}

\author{
Katarina Rupar, Mehri Sanati* \\ School of Biosciences and Process Technology, Växjö University, SE-35195 Växjö, Sweden \\ Received 23 June 2003; received in revised form 17 May 2004; accepted 10 June 2004 \\ Available online 11 September 2004
}

\begin{abstract}
During outdoor storage of large quantities of wood fuels, hydrocarbons are emitted into air in gas phase and leached out into the ground by precipitation. To investigate to what extent these emissions have environmental or health effects, sampling has been done on wood chip piles in an existing terminal storage situated in the south of Sweden, north east of Växjö. Sampling was done by solid phase microextraction (SPME) and analyzed on a gas chromatograph equipped with a mass spectrometer. The storage period, during which sampling was performed, stretches from June through January, a total of 200 days. Sampling was performed at 7 occasions. The results show that emissions into air increases when the temperature directly above the pile increases. The temperature above the pile decrease with the ambient temperature, up until September for the forest residue and October for the bark and root reducing wood chips, when the temperature above the pile suddenly increases. This could be due to the ambient temperature, the storage time or microbial activity.

The PAH content in the leachate, $27.27 \mu \mathrm{g} / 1$, does not seem to be in the range where it might give large effects on the environment.
\end{abstract}

(C) 2004 Elsevier Ltd. All rights reserved.

Keywords: Biomass storage; Organic emission; Terpenes; Volatile organic compounds; Gas chromatography

\section{Introduction}

The major part of the biofuels is directly transported to the thermal power plants and combusted within a few days. There is a need for a buffer for when no wood is being chipped, for example, during major holidays or during the

\footnotetext{
*Corresponding author. Tel.: + 46-0470-708943; fax: +460470-708756.

E-mail address: mehri.sanati@ibp.vxu.se (M. Sanati).
}

breaking up of the frost in the ground when heavy transports are not allowed on the small roads in the forests. Approximately $10 \%$ of the yearly production in Sweden is stored 5-10 months, but almost twice that amount passes through a storage terminal for a shorter period.

Transports longer than $50-100 \mathrm{~km}$ are not economically or environmentally viable, which means that the terminals must be placed near the power plants. This result in the terminal storage are placed close to where people live, often in small 
communities where there is an existing asphalted area, for instance a closed down factory of some kind. This results in people living close by complaining about odors and being worried if the emitted compounds are hazardous. There has also been a concern regarding fungal spores released from the storage.

There is a substance loss due to chemical and microbial decomposition of the biofuel during storage. Parameters influencing the storage are:

- Moisture content.

- Type of material.

- Age of the material.

- Size of the material.

There is very limited knowledge today about the release of hydrocarbons including terpenes during the storage of wood biofuels and thereby about the health effects or environmental impact. There have been a number of investigations, many Swedish, about the storage, but these have mainly focused on the substance loss or moisture- and temperature profiles within the piles during the storage [1-6].

Some health effects from terpene exposure are:

- Irritation to skin, eye and mucus membranes.

- Allergic and non-allergic contact dermatitis.

- Increased bronchial reactivity.

- Alveolar inflammation.

- Chronic lung function impairment.

- Acute changes in the upper and lower airway.

- Chest tightness.

- Inflammatory effects in the respiratory tract.

There have been a number of investigations on terpene levels and exposure in occupational environments such as sawmills, carpentries and joinery shops. The exposure measurements show large variations, the limits are sometimes exceeded, and sometimes not [7-13].

Many independent studies have shown an increased intensity of asthma, non-asthmatic airflow obstruction, upper and respiratory problems and sino-nasal cancer with exposure of softwood dust or monoterpenes [14-16].

The formation of ground level ozone and photochemical oxidants also results in health effects. The two main effects are irritation of eye and mucus, caused by secondary products such as aldehydes, and diminished respiration.

In the present work, the emission of terpenes into air and precipitation from different biomasses during storage was investigated. Solid phase microextraction (SPME) fibers were used for sampling, and analysis was performed using a gas chromatograph (GC) equipped with a mass spectrometer (MS).

\section{Experimental section}

\subsection{Biomass samples}

Air emission samples were taken on two different stored materials during a storage period of 200 days. The biomasses were bark/wood chips and forest residue chips, from soft wood, approximately $80 \%$ Pinus Sylvestris and 20\% Picea Abies. The biomasses were stored in large piles, approximately $7 \mathrm{~m}$ high and 50-m long. The piles were not intact during the sampling period, fuel for district heating was collected from them, but the samples were taken from the intact end of the piles. Leachate samples were taken at two occasions, in September and October.

\subsection{Chemical and material}

The SPME holder and SPME-coating fiber $100 \mu \mathrm{m}$ polydimethylsiloxane (PDMS) from Supelco were used in the sampling of emitted hydrocarbon compounds.

\subsection{Characterization methods}

The emissions from the stored biomasses were analyzed on a Varian Saturn 2000 GC equipped with a Saturn II ion trap MS detector. Chromatographic separations were performed using a Chrompack CP-Sil 8 capillary column $(30 \mathrm{~m} \times 0.25 \mathrm{~mm}$ I.D. $\times 0.25-\mu \mathrm{m}$ film $)$. An initial splitless injection was used for the first $5 \mathrm{~min}$, followed by split injection (ratio 1/100) for the remainder of the GC program. When a sample was injected, the oven temperature was kept constant 
at $30^{\circ} \mathrm{C}$ for $5 \mathrm{~min}$, then increased to $110^{\circ} \mathrm{C}$ (with a temperature increment of $20^{\circ} \mathrm{C} / \mathrm{min}$ ) and held for $5 \mathrm{~min}$, then increased further to $160^{\circ} \mathrm{C}$ (at $10^{\circ} \mathrm{C} /$ min increment) and held for $5 \mathrm{~min}$, then to $280^{\circ} \mathrm{C}$ (at $20^{\circ} \mathrm{C} / \mathrm{min}$ ) and held for $5 \mathrm{~min}$. Helium was used as a carrier gas, with a flow rate of $1 \mathrm{ml} / \mathrm{min}$, the injector temperature was $250^{\circ} \mathrm{C}$. The mass spectrum was obtained using an electron impact of $70 \mathrm{eV}$, with a filament emission current of $30 \mathrm{~mA}$, a mass range of $40-650 \mathrm{amu}$, and a scan rate of 2-scans/s.

\subsection{Sampling procedure}

The SPME experiments were performed using a manual SPME device with a 100- $\mu \mathrm{m}$ PDMS fiber assembly from Supelco. The SPME fibers were conditioned by inserting them into the GC injector according to the manufacturer's instructions. The fiber was exposed directly above $(1 \mathrm{~mm})$ the pile of stored biomass for $10 \mathrm{~min}$. After exposure, the fiber was transported to the laboratory and thermally desorbed for $5 \mathrm{~min}$ at $250{ }^{\circ} \mathrm{C}$ in the injection port of a GC. Sampling was performed at 7 occasions. Double samples were taken, but some of the double samples were lost due to breakage of the fiber.

The leachate was collected in September and October after days of high precipitation, there was enough leachate at the bottom of the pile to collect 11 from the ground. The temperature was mea- sured at the same position as the SPME fiber was placed, as close to the material of the pile as possible, approximately $1 \mathrm{~mm}$.

The ambient temperature and the precipitation were measured on each sampling occasion, approximately every other week. The attempt to measure the precipitation on the site failed when the temperature dropped below freezing, and was also possibly not completely accurate during the warmest periods of the summer. The precipitation data were taken from IVL Swedish Environmental Research Institute, Aneboda, not far from the site. The successful precipitation measurements in the beginning were compared to the ones from IVL and were found to correspond.

\section{Results and discussion}

\subsection{Temperature and precipitation}

The total precipitation during the sampling period was $435 \mathrm{~mm}$. Fig. 1 shows the precipitation during the sampling period.

The temperature $1 \mathrm{~mm}$ above the piles was measured on each sampling occasion. Fig. 2 shows the temperature variation in the ambient air and above the two piles. The temperature $1 \mathrm{~mm}$ above the piles follows the ambient temperature, except for in November where the temperature above the piles is higher than expected. This could be due to

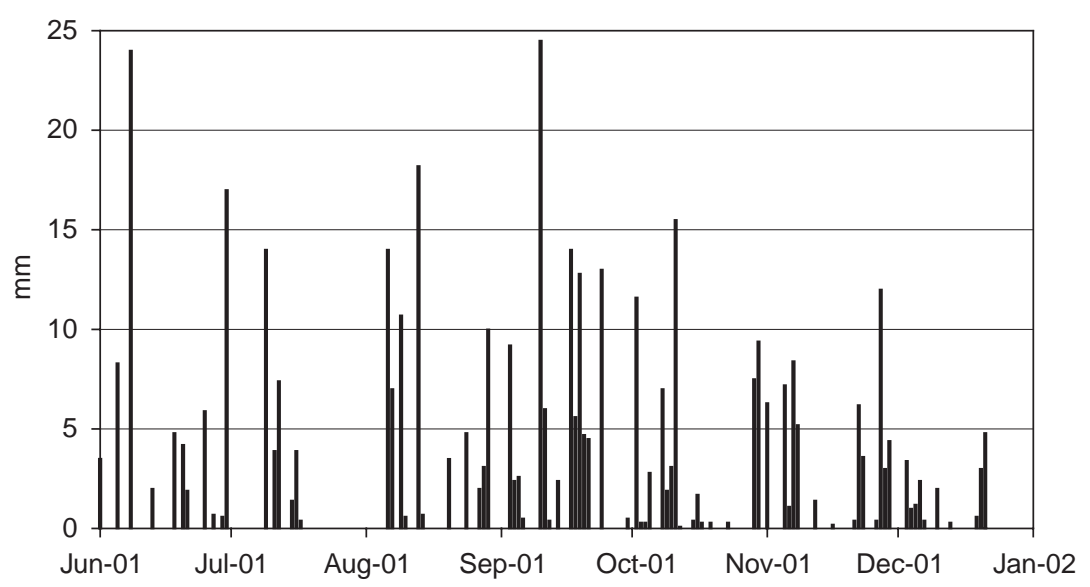

Fig. 1. Precipitation from June 2001 to January 2002. 


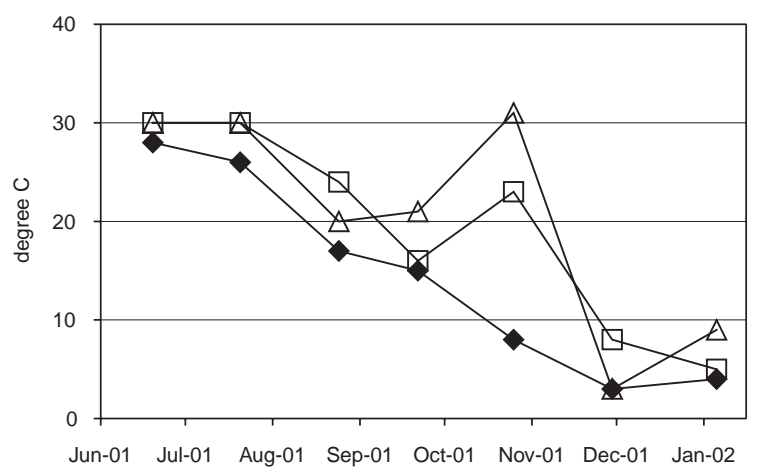

Fig. 2. Temperature $\downarrow$ ambient, $\square$ above the bark/wood chips and $\Delta$ forest residue.

microbial activity as a result of a longer period of large precipitation.

\subsection{Emissions to air}

The emissions from the bark/wood chips pile, Fig. 3, are high in the middle of the storage period and low in the beginning and end of the period. The emissions in September do not follow this trend; the emissions were lower. Horizontal bars display variation of replicates. The microbial activity in the wood chips pile was not considered in this work, however, there seems to be a correlation between the amount of precipitation and the emission levels. This is more obvious for the bark/wood chips, which is more sensitive for precipitation than the forest residues since the particle size of the material is smaller and the bark material is very porous. These are factors that also strongly affect any microbial growth.

The emissions from the forest residue, Fig. 4, are also high in the middle of the storage period and low in the beginning and end of the period. The emission level drops to a really low value already in November. Horizontal bars display variation of replicates.

Both the piles have the highest emissions in the autumn, October-November for the bark/wood chips pile, and September-October for the forest residue pile.

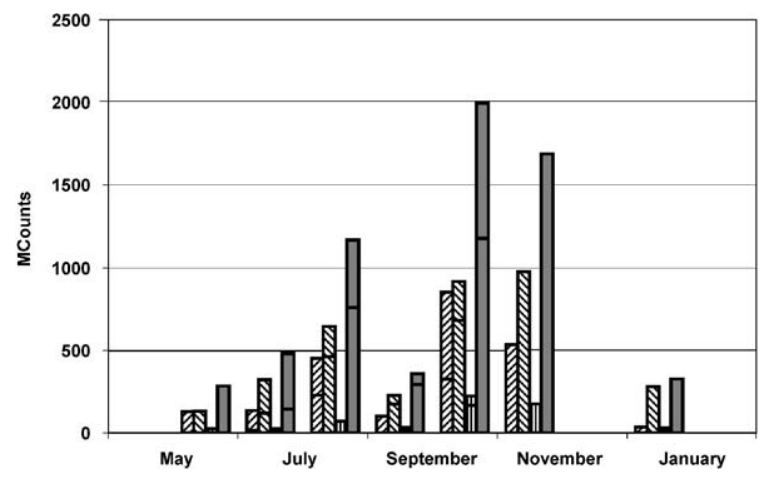

Fig. 3. $\square$ Mono terpenes, $\square$ sesqui terpenes, $\square$ di terpenes and $\square$ total emissions from the bark/wood chips pile. Horizontal bars display variation of replicates.

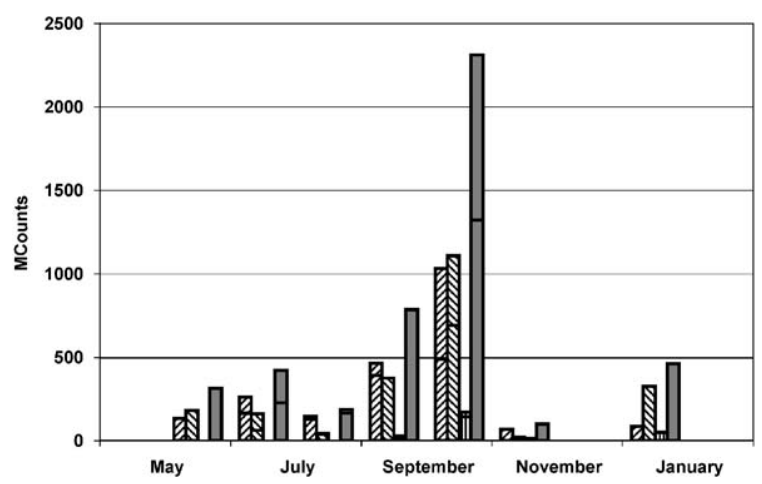

Fig. 4. $\square$ Mono terpenes, $\nabla$ sesqui terpenes, $\square$ di terpenes and $\square$ total emissions from the forest residue pile. Horizontal bars displays variation of replicates.

\subsection{Emissions to water}

Samples of leachate have been taken at two occasions, in September and in October. The leachate was qualitatively analyzed using SPME and GC-MS. The leachate from the bark/wood chips pile in September is more different from the leachate in October than the leachate from the forest residue pile in September. A sample from the bark/wood chips pile was analyzed for PAH, Table 1. The analysis was performed by IVL Swedish Environmental Research Institute. The result was $27.27 \mu \mathrm{g}$ PAH per litre. There were some difficulties to collect as much leachate as 11 , even 
Table 1

Identified and quantified PAH in leachate from the bark/wood chips pile

\begin{tabular}{rlll}
\hline No. & CAS & Compound & $\mu \mathrm{g} / 1$ \\
\hline 1 & $91-20-3$ & Naphtalene & 0.12 \\
2 & $91-57-6$ & 2-methylnaphtalene & 0.028 \\
3 & $90-12-0$ & 1-methylnaphtalene & 0.015 \\
4 & $92-52-4$ & Biphenyl & 0.024 \\
5 & $581-42-0$ & 2.6-dimethylnaphthalene & 0.0022 \\
6 & $208-96-8$ & Acenaphtylene & 0.022 \\
7 & $83-32-9$ & Acenaphtene & 0.0038 \\
8 & $2245-38-7$ & 2.3.5-trimethylnaphthalene & 0.010 \\
9 & $86-73-7$ & Fluorene & 0.079 \\
10 & $85-01-8$ & Phenanthrene & 2.2 \\
11 & $120-12-7$ & Anthracene & 0.037 \\
12 & $832-69-9$ & 1-methylphenanthrene & 0.26 \\
13 & $206-44-0$ & Fluoranthene & 3.7 \\
14 & $129-00-0$ & Pyrene & 2.7 \\
15 & $56-55-3$ & Benz[a]anthracene & 1.3 \\
16 & $218-01-9$ & Chrysene & 3.9 \\
17 & $205-99-2$ & Benzo[b]flouranthene & 5.6 \\
18 & $207-08-9$ & Benzo[k]flouranthene & 1.4 \\
19 & $192-97-2$ & Benzo[e]pyren & 2.4 \\
20 & $50-32-8$ & Benzo[a]pyren & 1.4 \\
21 & $198-55-0$ & Perylene & 0.16 \\
22 & $193-39-5$ & Indeno[1.2.3-cd]pyrene & 0.92 \\
23 & $53-70-3$ & Dibenz[a.h]anthracene & 0.095 \\
24 & $191-24-2$ & Benzo[ghi]perylene & 0.91 \\
\hline & & &
\end{tabular}

after high amount of precipitation. For the extreme case where all of the precipitations that theoretically can leach through a pile give this concentration, the emission of $\mathrm{PAH}$ to water is approximately $3 \mathrm{mg} / \mathrm{m}^{3}$ wood chips. The total amount of precipitation during the storage period was $438 \mathrm{~mm}$, and the size of the wood chips pile was approximately $7-\mathrm{m}$ high, 50-m long, with a base of $15 \mathrm{~m}$.

\section{Conclusions}

The storage period, during which sampling was performed, stretches from June through January, a total of 200 days. The emissions from both the bark/wood chips pile and the forest residue pile were low for the first 2-3 months of storage. The results show that emissions into air increases when the temperature $1 \mathrm{~mm}$ above the pile increases. The temperature above the pile decrease with the ambient temperature, up until September for the forest residue and October for the bark and root reducing wood chips, when the temperature above the pile suddenly increases. This could be due to the ambient temperature, the storage time or microbial activity.

The emissions increase with the amount of precipitation; this is however more true for the bark/wood chips pile. This can be interpreted as the bark/wood chips pile being more sensitive to precipitation than the forest residue pile.

The PAH content in the leachate, $27.27 \mu \mathrm{g} / 1$, does not seem to be in the range where it might give large effects on the environment, however, this needs further investigation.

If the temperature increase that gives rise to the emission increase could be correlated to microbial activity, substance loss and self-heating might be possible to avoid.

\section{Acknowledgements}

Financial support from Värmeforsk (Research and Development of the Thermotechnology), CECOST (The Centre of Combustion Science and Technology), and The Swedish Fire Protection Association (SFPA), is gratefully acknowledged.

\section{References}

[1] Thörnqvist T. Drying and storage of forest residues for energy production. Biomass 1985;7:125-34.

[2] Thörnqvist T. Large-scale seasonal storage of tree fuel project-summary of phase 1 . The Swedish University of Agricultural Sciences, Department of Forest Products, Report No. 188, 1986. ISBN 91-576-2913-7 [in Swedish with English summary].

[3] Nurmi J. The effect of whole tree storage on the fuelwood properties of short-rotation Salix crops. Biomass and Bioenergy 1995;8:245-9.

[4] Jirjis R. Storage and drying of wood fuel. Biomass and Bioenergy 1995;9:181-90.

[5] Nurmi J. The storage of logging residue for fuel. Biomass and Bioenergy 1999;17:41-7.

[6] Lehtinkangas P. Storage effects on pelletised sawdust, logging residues and bark. Biomass and Bioenergy 2000;19:287-93. 
[7] Eriksson KA, Levin JO, Sandström T, Lindström-Espeling $\mathrm{K}$, Lindén G, Stjernberg NL. Terpene exposure and respiratory effects among workers in Swedish joinery shops. Scandinavian Journal of Work and Environmental Health 1997;23(2):114-20.

[8] Dahlqvist M, Palmberg L, Bergström B, Ekholm U, Eriksson K, Figler B, Larsson B-M, Malmberg P, MüllerSuur C, Siljerrud S, Sundblad B-M, Ulfvarson U, Zhiping W. Akut exponering av luftföroreningar i sågverk hos friska försökspersoner. Arbetslivsinstitutet, arbete och hälsa 1996. ISBN: 91-7045-376-4.

[9] Svedberg U, Galle B. Assessment of terpene levels and workers' exposure in sawmills with long path FTIR. Applied Occupational and Environmental Hygiene 2000;15(9):686-94.

[10] Teschke K, Demers PA, Davies HW, Kennedy SM, Marion SA, Leung V. Determinants of exposure to inhalable particulate, wood dust, resin acids, and monoterpenes in a lumber mill environment. Annals of Occupatinal Hygiene 1999;43(4):247-55.

[11] Dahlqvist M, Palmberg L, Palmberg P, Sundblad B-M, Ulfvarson U, Zhiping W. Acute effects of exposure to air contaminants in a sawmill on healthy volunteers. Occupational and Environmental Medicine 1996;53:586-90.

[12] Demers PA, Teschke K, Davies HW, Kennedy SM, Leung V. Exposure to dust, resin acids, and monoterpenes in softwood lumber mills. American Industrial Hygiene Association Journal 2000;61:521-8.

[13] Rosenberg C, Ruonakangas A, Liukkonen T, Welling I, Jäppinen P. Exposure to monoterpenes in Finnish sawmills. American Journal of Industrial Medicine Supplement 1999;1:149-51.

[14] Kasanen J-K, Pasanen A-L, Pasanen P. Evaluation of sensory irritation of $\Delta^{3}$-carene and Turpentine, and acceptable levels of monoterpenes in occupational and indoor environment. Journal of Toxicology and Environmental Health Part A 1999;56:89-114.

[15] Demers PA, Teschke K, Kennedy SM. What to do about softwood? A review of respiratory effects and recommendations regarding exposure limits. American Journal of Industrial Medicine 1997;31:385-98.

[16] Falk-Filipsson A. Toxokinetict and acute effects of inhalation exposure to monoterpenes in man. Arbetsmiljöinstitutet, Arbete och Hälsa 1995:3. ISBN: 91-7045-294-6. 